\title{
Exchange rate regulation, the behavior of exchange rates, and macroeconomic stability in Brazil
}

\author{
FRANCISCO EDUARDO PIRES DE SOUZA \\ FERNANDO J. CARDIM DE CARVALHO*
}

In the last two decades an entirely new set of rules governing the foreign exchange transactions was established in Brazil, substituting for the framework inherited from the 1930s. Foreign exchange controls were dismantled and a floating exchange rate regime replaced different forms of peg. In this paper we argue that although successful by comparison to previous experiences, the current arrangement has important flaws that should be addressed. We discuss how it first led to high volatility and extremely high interest rates, which, when overcome, gave way to a long lasting appreciation of the real exchange rate with adverse consequences to industry.

Keywords: Brazilian exchange rate regime; capital account liberalization; foreign exchange regulation.

JEL Classification: E6; F3; F4.

\section{INTRODUCTION}

For the last twenty years, all federal administrations pursued, notwithstanding their eventual political and ideological differences, a continuous process of capital account liberalization. It represented a break with a tradition of controlling external

\footnotetext{
* Institute of Economics, Federal University of Rio de Janeiro. E-mails: fepsouza@uol.com.br and fjccarvalho@uol.com.br. This paper was extracted from a longer work, Carvalho and Souza (2009), written for the project Inestabilidad Financiera y Regulación en América Latina, directed by Roberto Frenkel, funded by the Ford Foundation, to both of which the authors extend their thanks. Submitted: 15/3/2010; Approved: 18/6/2010.
} 
financial flows which had its roots in the 1930s, in reaction to the Great Depression. As it frequently happens with momentous policy changes in Brazil, it has been a slow, gradualist process where major decisions were made in a rather opaque way and not always respecting appropriate legal rituals (Franco and Pinho Neto, 2004).

Midway in this liberalization process, another major institutional change took place - in this case, all of a sudden, induced by a balance of payments crisis: the substitution in January 1999 of a floating exchange rate regime for the crawling peg arrangement implemented in early $1995^{1}$.

As a result, Brazil entered the first decade of the XXI century with an entirely new institutional framework governing demand and supply of foreign exchange and the determination of the exchange rate. By allowing transactions in the foreign exchange market for the purpose of buying and selling virtually any financial and real assets, liberalization of the capital account made the exchange rate behave increasingly like the price of an asset. Meanwhile, the floating rate regime left it to the market - now a much wider market than in the past - the determination of the price of this asset, which incidentally is one of the most important macro prices in the economy.

To evaluate how well has this new arrangement fared is not an easy task. First of all because so many changes were taking place at the same time in economic policy and institutions that it is difficult to disentangle or control the effects of other determinants of the exchange rate and the macroeconomic situation. Second, because the international economy also gyrated so much in this period, oscillating between times of great volatility in financial flows and economic performance - as during the Asian crisis - and times of great prosperity and stability - as the 2003-2007 period $^{2}$. As a consequence, we had both periods of great volatility and low volatility, as well as phases of depreciated and competitive exchange rates and long phases of appreciation and low competitiveness. Therefore, what looked like a regime able to guarantee a competitive exchange rate and a solid balance of payments in the first half of the 2000s, did not show the same assumed properties in the second half of this decade.

It is not the objective of this paper to test the performance of this exchange rate regime econometrically. Instead, it aims to make a broad appraisal of the question drawing on some features of the macroeconomic overall performance and some structural developments that may be associated with the exchange rate regime adopted at the time, and raise questions concerning the appropriateness of this

\footnotetext{
${ }^{1}$ Although sometimes referred to as a band system, the exchange rate regime originated in July 1994 and reformed in April of 1995, was in fact an active crawling peg as defined by Corden (2002, ch. 5). The wider band within whose limits the exchange rate was supposed to float (if a genuine band regime were in place) was fictitious, since the Central Bank in fact determined a very stable path - with virtually no floating — for the currency price. See Souza (1999).

${ }^{2}$ The second difficulty is easier to deal with in a panel study with many countries and different exchange rate arrangements, in as much as all the economies would be facing similar external determinants. The same can not be said of the first one.
} 
regime. We begin, in the next section, by taking stock of the process of opening the capital account in order to have a broad qualitative picture of the degree of financial integration in the world economy reached at the period and its consequences for the foreign exchange market. The following two sections discuss some key macro and structural developments related to the exchange rate regime in two different phases: the first, from 1997 to 2003 characterized by high volatility and (since the adoption of the floating regime in January 1999) a depreciated exchange rate; the second, from 2004 on, characterized by a long appreciation process, with incipient, although important, consequences on economic structure, specially the structure of exports. The last section concludes.

\section{CAPITAL ACCOUNT CONVERTIBILITY: MAIN STEPS}

The earliest attempts to liberalize the capital account, since the crisis of the 1930s, date back to 1962 with the passing of Law 4131, which guaranteed the "right of return" and of profit remittances to foreign direct investments, loans and other forms of finance. It was under these legal rules that Brazil joined the emerging market for Eurodollars in the 1960s and 1970s. The debt crisis of the early 1980s, however, interrupted the trend towards liberalization. Capital controls were hardened while the country was excluded from the international financial system for almost a decade.

However, by the end of that decade and beginning of the 1990s, capital controls had been abolished in the advanced economies and developing economies, with a few notable exceptions, were also moving in that direction. It was in this environment that the Brazilian authorities decided to restart the capital account liberalization process.

The first major steps towards capital account convertibility were taken between 1988 and 1992 through three main initiatives of deep impact ${ }^{3}$ : the creation of a segment of the exchange market where rates were allowed to float freely; the opening of domestic securities markets to foreign investors; and the permission to transfer financial resources abroad without proof of previous internment through the so-called CC5 accounts. Once these rather radical changes were implemented, capital account liberalization was pursued further through less momentous initiatives.

The floating exchange rates market was created in 1988 while the overall exchange market was still ruled by a crawling peg regime. The new regime applied only to operations that used to be forbidden or strictly controlled. One important result of this measure was the virtual disappearance of the black market as more and more types of transaction were allowed under the new rules.

\footnotetext{
${ }^{3}$ For details of the referred policy initiatives, not only related to the capital account but also to current transactions since 1988, see Souza (1993), Carvalho, Hoff and Souza (2008), Franco and Pinho Neto (2004) and Cintra and Prates (2005).
} 
The most important initiative with respect to the capital account was, surely, the lifting of restrictions to foreign investment in domestic securities markets. Once the so-called "Annex IV" mechanism was established, foreign investors answered quickly to the new opportunities and increased decisively their presence in these markets.

The exit of financial investments by residents was also facilitated. The changes introduced in CC5 accounts allowed financial institutions operating in the domestic market to transfer abroad not only their own resources but also any deposits made with them for the same purpose, without any need to prove that these resources had been previously brought into the economy. It was a underhanded move to allow residents to buy assets abroad, circumventing the principles underlying Law $4131^{4}$.

Within this regulatory framework, the Brazilian economy returned to the international financial system even before the debt crisis was resolved, with the successful debt renegotiation under the Brady Plan, in 1994. The strong recovery of capital inflows between 1992 and 1994, including the newly-allowable investments in the local stock exchanges, confirmed the authorities' expectations, as it is shown in Table 1.

Table 1: Main Net Capital Flows to Brazil (US\$ billion)

\begin{tabular}{|c|c|c|c|}
\hline Flow & 1982-1991 & 1992-1994 & 1995-1998 \\
\hline Foreign direct investment ${ }^{1}$ & 0,6 & 1,2 & 13,8 \\
\hline Net portfolio equality inflows & 0,0 & 4,9 & 4,1 \\
\hline Net debt flows ${ }^{2}$ & $-0,8$ & 9,9 & 10,7 \\
\hline
\end{tabular}

(1) Exc. Conversion of debt into FDI.

(2) Exc. New money on non voluntary basis and Monetary Authority flows.

Source: prepared by the authors on the basis of Central Bank data.

The honeymoon with the international financial system was abruptly, but briefly, interrupted by the Tequila effect, the contagion of the Mexican crisis of 1995 to the Brazilian economy. The crisis that began in late 1994/early 1995 had a serious impact on the domestic banking sector (see Carvalho and Souza, 2009, section 3). In terms of the country's balance of payments, however, it was the Asian crisis that marked a really critical moment. The strong instability of international capital flows to developing economies initiated with that crisis ultimately led to the balance of payments crisis of 1999 and the abandonment of the exchange rate regime adopted in 1994.

The 1999 crisis represented a cross-roads for the strategy pursued for so long. As reported by then-chairman of the Central Bank of Brazil, Francisco Lopes (2003),

\footnotetext{
${ }^{4}$ Doubts whether the changes were lawful or not led the Central Bank to issue a manual (Banco Central, 1993) where it was stated that there was nothing wrong with the decision of a plain Brazilian citizen to dispose of her savings in whatever way she wishes, comprising sending it abroad, provided that taxes were paid.
} 
at that moment the authorities were faced with two alternatives: to reestablish capital controls and declare moratorium to try to rescue the exchange rate regime or to move towards floating exchange rates. The final decision was made by President Cardoso, who chose the second alternative.

Balance of payments adjustments were not smooth in the first years after the adoption of floating exchange rates. Nevertheless, even though a "crisis mood" prevailed at that time, and at least two episodes of sudden stop in capital inflows took place, in 2001 and 2002, the liberalizing strategy for the capital account was not abandoned ${ }^{5}$.

The period after 2002 was, in contrast with the immediate past, marked by stable capital flows. The Argentine crisis of 2001-2002 and the first election of President Lula da Silva in 2002 represented the latest tests to which the new monetary and exchange rate domestic architecture was submitted. From that time on, increasing foreign capital inflows seems to have encouraged the Lula administration to proceed with capital account liberalization. In the new phase, further measures were adopted, among which the most important were: i. the unification of the exchange market; ii. the elimination of limits to dollar positions held by domestic banks; and iii. the end of the requirement that exporters should internalize their dollar revenues (cobertura cambial).

The unification of the exchange market ${ }^{6}$, in March 2005, was simultaneous with the permission for residents to freely transfer financial resources abroad, revoking thereby the rules connected to the CC5 account, which was extinguished. Thus, only a few marginal restrictions were left in the book in respect to placements abroad, mainly related to investments by domestic institutional investors. These institutions are regulated by specific dispositions, which have also been made more flexible lately.

The second measure was, in some respects, a consequence of the first. Under floating exchange rates, to the extent that the rate is really left to float freely, with only occasional intervention by the Central Bank ${ }^{7}$, the role of market maker was shifted from the monetary authority to banks. In order to perform this role, banks needed to keep a bigger inventory of foreign currencies than before. For this reason, the Central Bank decided to eliminate the (low) ceilings it used to impose on the foreign currency reserves held by banks in January 2006. Thus, one of the last remnants of the Central Bank's monopoly of foreign exchange was eliminated and the decision to hold or not foreign currency in their portfolios became one of the

\footnotetext{
${ }^{5}$ On the contrary, some additional decisions were made in the same direction, such as accepting current account convertibility, as set by Article VIII of the IMF's Articles of Agreement, effective November 1999 (Franco and Pinho Neto, 2004, pg 22).

${ }^{6}$ In reality, both were floating rate markets. Nevertheless, access was segmented according to type of payment, besides some differences of rules applying in each market.

${ }^{7}$ A detailed analysis of these interventions is provided by Souza (2005).
} 
major elements of banks' financial strategies, introducing a new element in the set of determinants of the exchange rate.

Finally, in August 2006, a process was initiated that was ultimately to lead to the extinction of the last pillar of the exchange control regime created in the 1930s: the mandatory internment of export revenues ${ }^{8}$. The National Monetary Council, Brazil's main financial regulator (CMN, in the Portuguese acronym), at first reduced the requirement to $70 \%$ of revenues, but kept reducing it until it reached $0 \%$, in March 2008, so that exporters also now face the choice of internalizing or not their revenues in foreign currency, increasing still further the power of the "market" in the determination of the exchange rate.

In sum, in the first years of the new millennium, the exchange control structure created in the aftermath of the Great Depression was dismantled brick by brick in a process that is pretty much completed by now. Market considerations tended increasingly to prevail over policy design so that the exchange rate became more and more a market-determined price. This change was strengthened by the development of derivative contracts and by the issuance of public debt securities indexed to the exchange rate in moments of fragility in the balance of payments, which opened a wider field of possibilities for arbitrage operations. The enlargement of the market for foreign currency, on its turn, shaped the way the floating exchange rate regime was to operate, something to which we will return later.

To evaluate the performance of the present Brazilian exchange rate regime in an environment of an open capital account, it is important to keep in mind that if capital account convertibility took a somewhat long time to be completed, the decisive changes took place in the early 1990s. There is enough experience with a liberalized foreign currency market to at least allow some hypothesis to be raised about the efficiency of these arrangements. To do this assessment, it is convenient to consider two subperiods. The first goes from the Asian crisis to 2002, and is characterized by a combination of domestic fragilities and a turbulent international environment. The second period covers the post-2003 years, when both the domestic and the international pictures become much more favorable.

\section{FINANCIAL INTEGRATION AND VOLATILITY: 1997-2003}

As shown in Table 1, capital inflows were much increased as a consequence of the permission granted to foreign investors to participate in domestic securities markets. These capital inflows gave an important contribution to the success of the Real Plan, allowing the government to make a credible commitment to the maintenance of an exchange rate anchor. Other possible benefits, such as the absorption

\footnotetext{
${ }^{8}$ Before those changes, it was required that the exporter internalized revenues before being able to remit money again through the other facilities that were mentioned. The process, of course, was much more expensive, involving paying taxes, fees etc., than the alternative of simply depositing the revenues in a foreign financial institution.
} 
of foreign savings or the push to increase domestic productivity, are much more controversial. The appreciation of the local currency induced by capital inflows seemed to substitute foreign for domestic savings rather than increasing the total pool of savings (Bresser-Pereira and Nakano, 2002). On the other hand, if an appreciated exchange rate helped to increase productivity by cheapening imports of capital goods, it also caused a severe loss of competitiveness in the manufacturing sector ${ }^{9}$.

But the appreciation of the domestic currency does not exhaust the impacts of the new exchange rate regime on the Brazilian economy. It is important to consider, in this period, also the impacts of the increased volatility of variables such as exchange rates and capital flows. After an initial period in which benefits from increasing access to capital flows seemed to outweigh losses, a new stage began marked by a greater scarcity of capital and volatile capital flows, including a few sudden stop or even downright capital flight episodes. Graph 1 shows that in the aftermath of the Asian crisis net inflows of voluntary capita $1^{10}$ decreased and became negative in some years. Loan flows and portfolio investments were particularly hit, in contrast to direct investment where momentum was maintained by the continuity of the privatization process in the 1990s.

Graph 1: Net Capital Flows to Brazil (US\$ million)

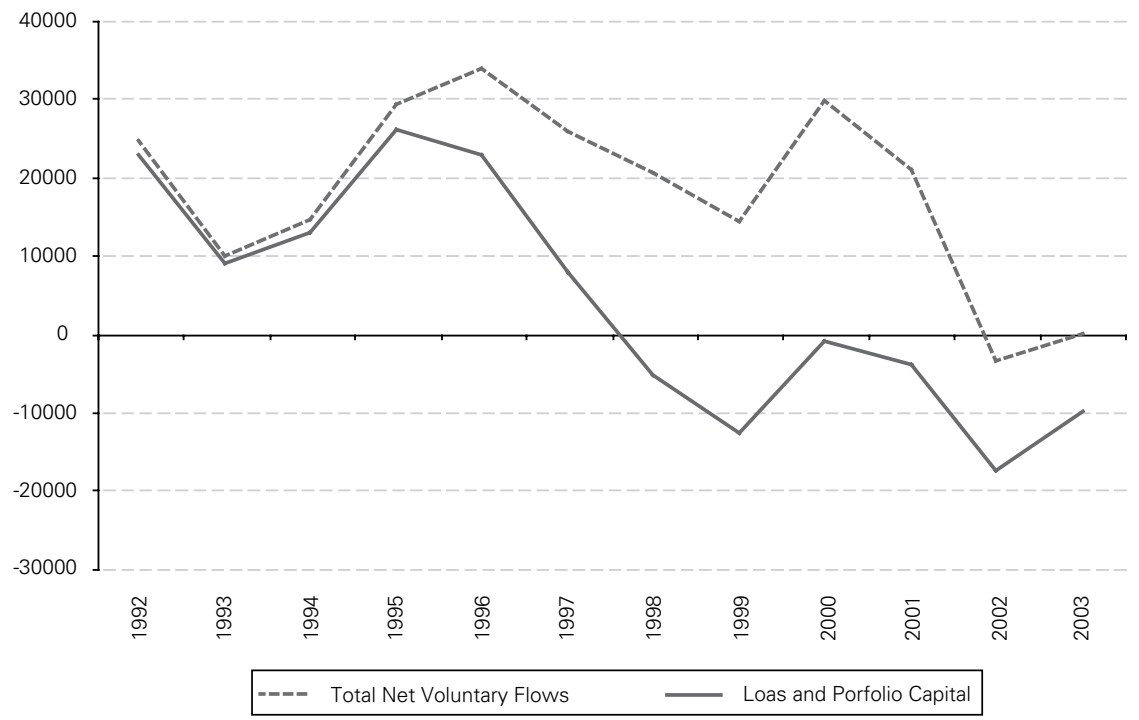

Source: prepared by the authors, on the basis of Cental Bank Data.

\footnotetext{
${ }^{9}$ To have an idea of the debate between those defending the view that exchange rate appreciation helped to increase productivity and those pointing to the opposite result, see Pastore (2008) and Gala (2009).

${ }^{10}$ Voluntary capital flows are obtained by subtracting from total flows those of compensatory loans to the Monetary Authority.
} 
To evaluate the magnitude of the macroeconomic impacts of sudden stops and capital flight, beginning with the Asian crisis, one needs to consider also what happened with the current account. While capital inflows expanded, the appreciation of the real led to an increase in current account deficits, the peak of which was reached precisely when capital inflows dried down. As a result, financing gaps emerged to which there were no willing lenders in the international financial system.

Graph 2 shows data for accumulated financing gaps in twelve months (measured as the difference between the net flow of voluntary capital and the deficit in current account) between 1995 and 2003. One can see that the financing gap has remained very high for extended periods of time. The most critical moment, doubtlessly, was the time around the exchange rate crisis (twelve months to April 1999), when the cumulative gap reached about US\$ 48 billion.

The wide fluctuations in external financing were transmitted to domestic macroeconomic variables through a mechanism that can be stylized as follows: the contraction or standstill of capital inflows made foreign currency scarce, forcing either a loss of reserves and/or a strong devaluation of the real. The Central Bank then raised sharply domestic interest rates to stop the loss of reserves or to contain the inflationary consequences of the currency devaluation. Rising interest rates caused then a recession. Since these shocks were frequent, the whole economy became volatile, shortening the duration of economic cycles.

Graph 2: Foreign Financing Gap (12 month data, in US\$ million)

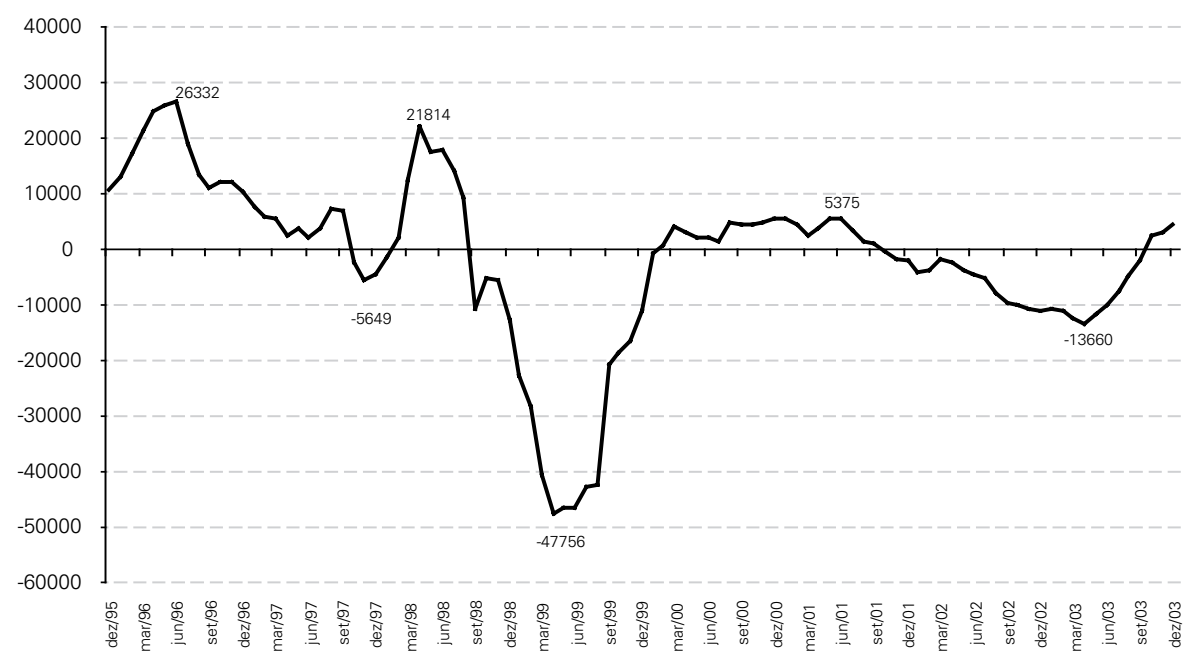

(1) Nel Voluntary Capital Flows less Current Account Deficit.

Source: prepared by the authors, on the basis of Cental Bank Data.

Both financial and non-financial firms had to struggle to survive in this hostile environment. As a result, markets for derivatives and other hedging instruments 
thrived. Excess volatility in the late 1990s, however, ultimately distorted the operations of these markets forcing the government to act intensely to contain exchange rate movements in future markets. What resulted was a situation in which private agents could find protection against strong exchange rate changes caused by a contraction in capital inflows in the dollar-linked securities issued by the government who assumed the exchange rate risk. The government exposed itself to exchange rate risks supplying private investors with an almost unlimited hedge against balance of payment disturbances. The price of this arrangement was the quick and deep deterioration of the fiscal position in crisis times (see Carvalho, Silveira and Souza, 2008).

The peculiar allocation of exchange rate risks between private and public sectors allowed the economy to sail through moments of balance of payments difficulties without more serious damages, since private agents' balance sheets were preserved. However, the deterioration of the fiscal position of the federal government worsened the evaluation of the Brazilian economy's perspectives by foreign investors, increasing the risk premium of loans to Brazilian borrowers and reducing credit to the country, deepening the balance of payments problems. To improve its perspectives, the federal government cut expenditures or increased taxes, causing the economy to contract. The volatility of the Brazilian economy was thus amplified by a fiscal pro-cyclical policy.

\section{FINANCIAL INTEGRATION, EXCHANGE RATE APPRECIATION AND LOSS OF INDUSTRIAL DENSITY: 2004 TO?}

As the 2000s went by, some important institutional changes, as well as overall improvements in the economy, made it possible to overcome or attenuate the degree of instability characteristic of Brazil's recent growth patterns, as just described. A central element of the new picture was the contraction of Brazil's external debt made possible by the accumulation of current account surpluses in the aftermath of the balance of payments crisis of 1999. The ratio between net foreign debt to total exports fell from 3.6 in 1999 - which put the country in the category of "severely indebted" in the World Bank classification - to a net creditor position in 2007, as can be seen in Table 2. A parallel improvement in fiscal solvency also marked the period. 
Table 2: Reserves, Net External debt and current account

\begin{tabular}{c|c|c|c}
\hline Year & $\begin{array}{c}\text { International Reserves } \\
\text { (US\$ Billion) }\end{array}$ & $\begin{array}{c}\text { Net External Debt/ } \\
\text { Export of Goods }\end{array}$ & $\begin{array}{c}\text { Current Account } \\
\text { Balance/GDP (\%) }\end{array}$ \\
\hline 1999 & 36,3 & 3,6 & $-4,3$ \\
2000 & 33,0 & 3,1 & $-3,8$ \\
2001 & 35,9 & 2,8 & $-4,2$ \\
2002 & 37,8 & 2,7 & $-1,5$ \\
2003 & 49,3 & 2,1 & 0,8 \\
2004 & 52,9 & 1,4 & 1,8 \\
2005 & 53,8 & 0,9 & 1,6 \\
2006 & 85,8 & 0,5 & 1,3 \\
2007 & 180,3 & $-0,1$ & 0,1 \\
2008 & 206,8 & $-0,1$ & $-1,8$ \\
\hline
\end{tabular}

Source: Banco Central do Brasil, "Nota para a Imprensa do Setor Externo" and "Indicadores Econômicos Consolidados"

As fragility factors were removed, macroeconomic volatility fell substantially. Interest rates, for instance, fell to unheard of levels in the last fifteen years, even though they still remain above international standards. In the new circumstances, the Brazilian economy seemed to begin growing sustainably for the first time in more than two decades.

It should not be surprising that foreign investors became enthusiastic about the economy's perspectives. Reaching investment grade in 2008 was at the same time an indication and a strengthening factor of these tendencies. Accordingly, capital inflows grew in size and became more stable, as it is shown in Graph 3. This picture lasted until the last quarter of 2008, when the shock waves generated by the failure of Leman Brothers finally brought the international crisis to Brazil. A byproduct of the newly reached good times, however, was the sustained appreciation of the real ${ }^{11}$, again, not only with respect to the US dollar but also in reference to a varied basket of currencies, as shown in Graph 4. In September 2008, the effective rate of exchange was $42 \%$ above its level in the first semester of $2004^{12}$.

\footnotetext{
${ }^{11}$ Many analysts confer a decisive role to current account elements in the explanation of the behavior of the exchange rate. Even if these factors had performed in the way these analysts assumed, it is important to point out that even when the current account balance was reduced in 2007 and 2008, the appreciation of the real was not stopped or reversed. In fact, it became stronger, suggesting a decisive influence of the capital account.

${ }^{12}$ Measured by the fall in the value of a basket of currencies with respect to the real. If we measure it by the increase in the value of the real with respect to the basket of currencies, appreciation is set in $71 \%$.
} 
Graph 3: Net Capital Inflows (exc. Monetary Authorities) in US\$ million

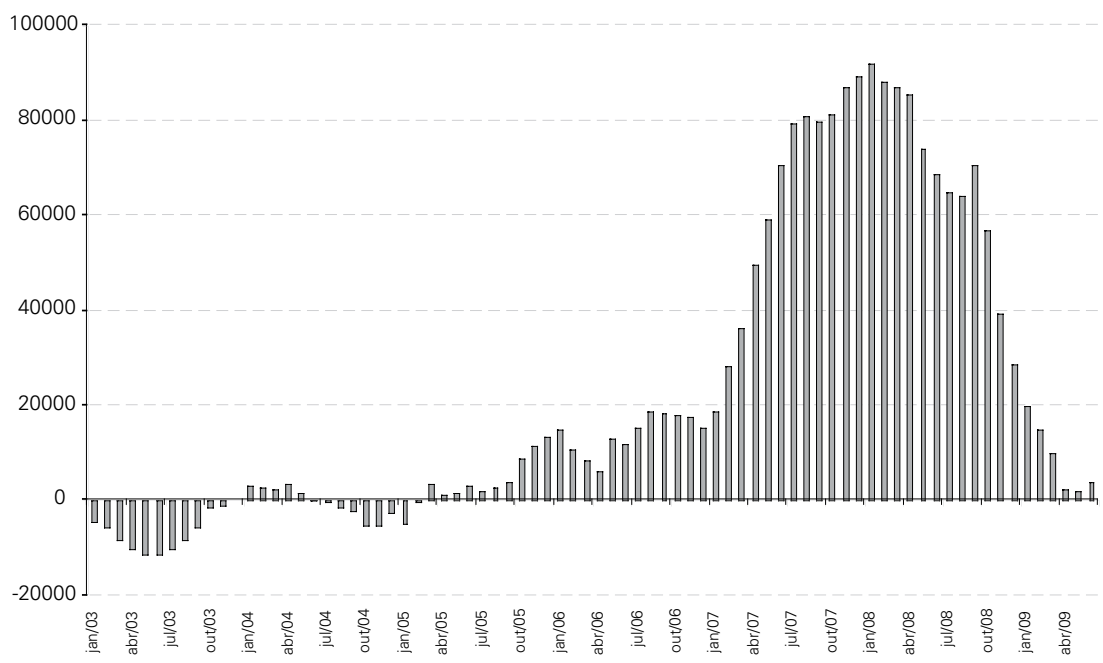

Source: Banco Central do Brasil

Graph 4: Real Effective Exchange Rate Index (June 1994 = 100)

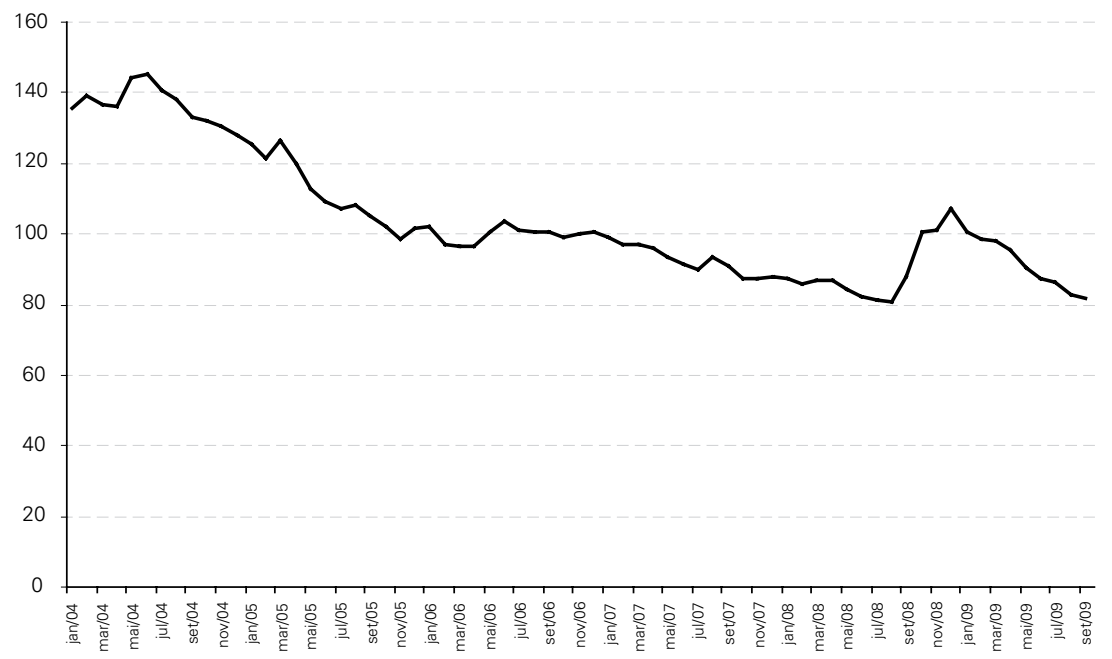

Source: Banco Central do Brasil

All things considered, one cannot avoid qualifying the apparent virtuous circle installed in the country in recent years. What seems at first sight to be a continuous process of economic expansion initiated in the second semester of 2003, is in fact a process in which a fundamental change is occurring both in growth patterns and in 
the mode the Brazilian economy is integrated in the world economy. The appreciation of the real has made exports, and especially exports of manufactured goods, to lose impulse. The manufacturing sector also lost competitiveness with imported goods in the domestic market. The apparently paradoxical coexistence between growth and loss of competitiveness was in fact made possible by the vigorous expansion of domestic demand sustained by the strong growth in the credit supply.

To put it in more concrete terms, if net exports' contribution to economic growth is increasingly negative, only a strong expansion of domestic demand can sustain growth. The strong expansion of domestic demand in itself is, of course, to be desired, but if its rate of growth is higher than that of GDP, year after year, the result is an increasing deficit in the ratio of current account do $\mathrm{GDP}^{13}$. The first indications that this is currently happening are already visible in the last line of Table 2.

Growth patterns are also changing when looked at from the supply point of view. The structure of production, and, again, especially of exports, are being transformed, as manufacturing production and exports lose importance in comparison with foreign competitors, due to the exchange rate appreciation. Since 2005 Brazilian exports of manufactured goods have stagnated, when measured in volume, despite the fact that international trade in this class of goods had expanded continuously until it collapsed in the last quarter of 2008, under the weight of the world recession. The rather obvious consequence of these developments is the loss of market share in world markets, as shown in Graph 5.

\section{Graph 5: Brazilian exports of manufatctures in volume/World exports of manufactures in volume (Index, $1993=100)$}

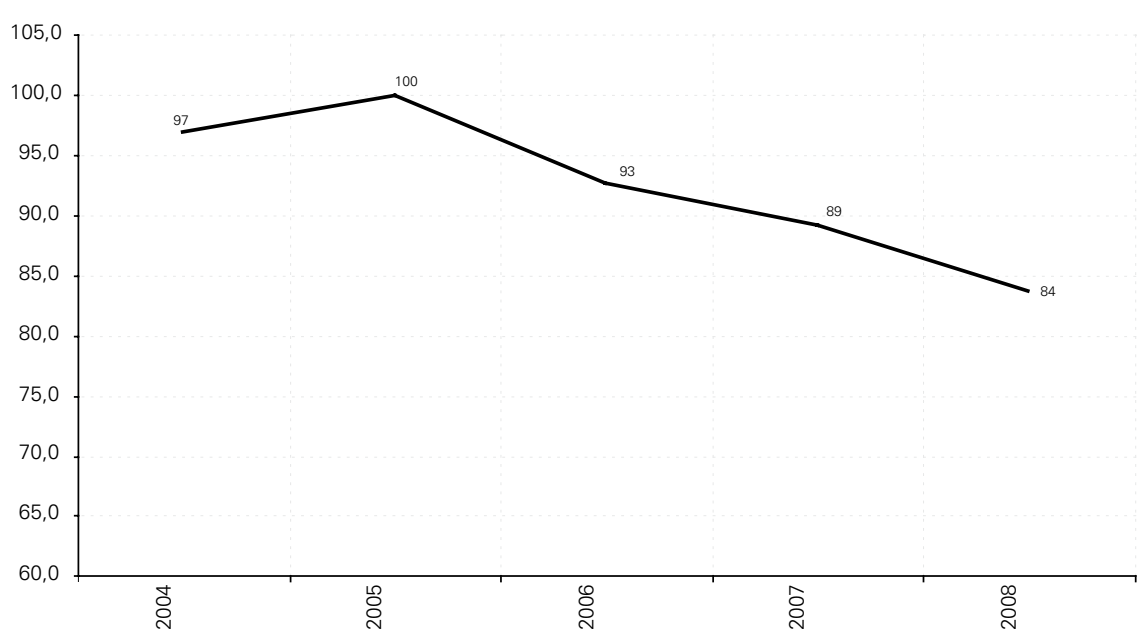

Sources: Funcex; UN, Monthly Bulletin of Statistics; WTO.

\footnotetext{
${ }^{13}$ Not to speak of the possible problems created by an expansion of demand sustained by increase in credit rather than increase in incomes.
} 
Not only has Brazil been losing space in the international market for manufactures but this class of goods is also losing room in total exports of the country, as can be seen in Graph 6. In addition, the degree of diversification of exports is also decreasing ${ }^{14}$, making the country potentially more vulnerable to changes in world demand patterns. All together, these trends imply a reduction of the share of the manufacturing sector in Brazilian GDP, while mineral exploration and exports expand theirs.

Graph 6: Brazilian Exports by Class of Product (\% based on 12 month accumulated values)

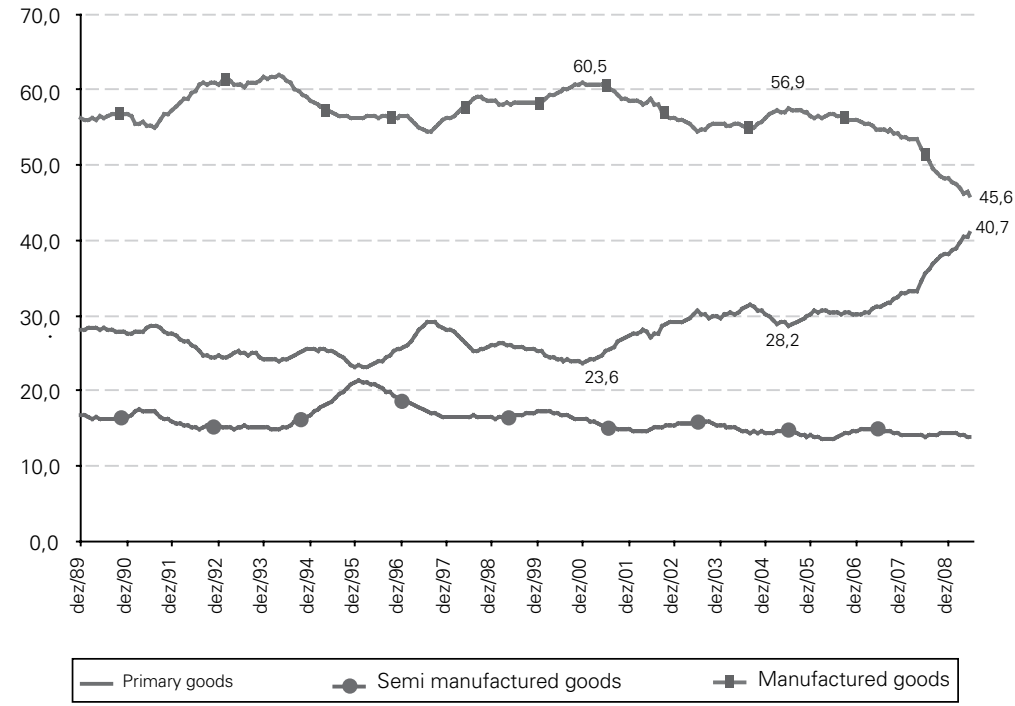

Source: MDIC/Secex

The changes just described are in their initial stages. They are strengthened, however, by developments taking place outside Brazilian borders. The most important factor, of course, is the rise of China in world GDP and international trade. China is a great exporter of manufactures (pushing their prices down) and a great importer of commodities (pushing their prices up). China's role is not new, but the depth of its impact is.

All the elements discussed in this section join up to draw a dangerous picture for the future development of the Brazilian economy. In the next few years, because of the likely return of the external vulnerability associated to rising deficits in the current account. In a longer view, because the eventuality of an excessive degree of specialization in exports of commodities could make its balance of payments vola-

\footnotetext{
${ }^{14}$ Notwithstanding the fact that the exchange rate has appreciated since the end of 2002, it remained on very depreciated absolute levels until at least the end of 2004. Only in the following years did the appreciation of the exchange rate begin to impair the performance of manufacturing exports. For a detailed account of this subject, see Souza (2009).
} 
tile, dependent on changes in the terms of trade ${ }^{15}$. Finally, because an excess degree of specialization in the production of a few goods can affect negatively the dynamism of a large economy like Brazil's.

The competitiveness of Brazil in the face of foreign competitors cannot be left to the whims of international financial investors ${ }^{16}$. That their influence is as important as it presently is bears witness that there is something wrong with the economic policy regime, and, in particular with the exchange rate regime.

In fact, when the floating exchange rate regime was introduced in 1999, it was supposed to adjust the balance of payments, freeing other macro policies to pursue domestic goals. In particular, two expected promises were not warranted. First, many economists expected that, free from the need to attract foreign capital to meet current account deficits, during the frequent international financial turbulences, interest rates would soon achieve "normal" (by any international norm) levels as well as being less volatile than it was in the past. Besides that, at the beginning of the 2000s it was a general belief that the floating regime, in contrast with the exchange rate anchor regime, would make sure that the value of the currency would always be consistent with the preservation of the competitiveness of the domestic industry.

However, as discussed in the previous section, volatility remained very high during the first years of the new exchange rate regime and interest rates, although lower than in the past, were kept at abnormally high levels by comparison to any international standard, breaking the first promise. After 2003, however, macroeconomic and financial volatility diminished, but the ensuing growth of demand for Brazilian assets brought about a continuing process of exchange rate appreciation, that eventually led to a dismal performance of the exports of manufactures and to a process of deterioration of the current account, breaking the second promise.

Nevertheless, the fact that under this policy regime the country has been able to maintain low rates of inflation and a productive performance that is far from the brilliance of Asian countries, but is no longer stagnating as it happened in the last twenty-odd years, has prevented the serious consideration of alternatives. A certain degree of disenchantment with the "heterodox" policy experiments of the past has weighed in the same direction.

\footnotetext{
${ }^{15}$ Carvalho, Silveira and Souza (2008) have shown how the process of diversification of Brazilian exports that took place mainly between the mid 1960s and the mid 1980s have made the balance of payments as well as the growth of the economy very insensitive to changes in the international prices of commodities since then.

${ }^{16}$ From May to August 2009, amidst a growing euphoria regarding the end of the crisis - and, particularly, a renewed international optimistic mood with respect to the Brazilian economy - there has been a net inflow of US\$12,4 billion in foreign capital to the São Paulo Stock Exchange. This was by far the largest component of the capital inflows in the period and coincided with a $15 \%$ appreciation of the real.
} 


\section{CONCLUSION}

By the last quarter of 2008, the international crisis initiated in the United States the year before finally hit Brazil. Among its chief manifestations, a capital flow reversal took place, devaluing the real. Moreover, the devaluation of the real itself, caught by surprise many investors, generally large non-financial firms, who had bet on the continuing appreciation of the Brazilian currency through derivatives. The heavy losses suffered by these investors led to a sense of heightened uncertainty and amplified the domestic impact of the international crisis contagion.

The devaluation of the real, however, was short-lived. Already in 2009, although the contractionary impact of the crisis still lingered for some quarters, capital inflows were resumed and the domestic currency began to appreciate again. Trying to decelerate this trend, the Finance Ministry took one step back in the process of capital account liberalization, imposing a $2 \%$ tax on capital inflows. Liberal circles and financial market agents loudly condemned the initiative, although at such a short rate, it was expected to be little more than symbolic. In fact, the imposition of this mild form of capital control in Brazil was followed by similar initiatives in other countries, beginning with Taiwan and it did signal a change in the dominant assessment of the efficacy of capital controls. Perhaps more surprising, the move ended up receiving some support from the most unexpected source, the IMF. In a widely discussed staff note, Fund's staffers conceded that under certain conditions "capital controls are a legitimate part of the toolkit to manage capital inflows" (Ostry et al., 2010, p. 15). The rather obvious qualification that controls may be effective only "in certain conditions", which is a valid clause in fact with respect to any policy "tool", did not disguise the about-face performed by the Fund, after almost twenty years of active prodding toward liberalization.

The new environment creates the opportunity to look for alternatives of a more stable and competitive exchange rate policy. It is probably not the case of returning to an exchange rate peg, that would be an easy target for speculative attacks, as we have learned in the 1990s. But as more instruments are incorporated to the repertoire of economic policy, it makes it easier to have goals for the exchange rate, although not necessarily fixed exchange rates or even explicit rate targets.

\section{REFERENCES}

BANCO CENTRAL DO BRASIL (1993) “O regime cambial brasileiro: Evolução e perspectivas”, Diretoria de Assuntos Internacionais, Brasília, novembro.

BASEL COMMITTEE ON BANKING SUPERVISION - BCBS (2009), Enhancements to the Basel Framework, July, www.bis.org.

BRESSER-PEREIRA, L.C. and Y. NAKANO (2002) "Economic growth with foreign savings?" Paper presented to the Seventh International Post Keynesian Workshop Kansas City, Missouri. Available at: http://www.bresserpereira.org.br/view.asp?cod=982.

BRUNNERMEIER, M., A. CROCKETT, C. GOODHART, A. PERSAUD and H. SHIN (2009) “The 
fundamental principles of financial regulation”, International Center for Monetary and Banking Studies, Geneva.

CARVALHO, F.J.C. (1998) “The real stabilization plan and the banking sector in Brazil”, Banca Nazionale del Lavoro Quarterly Review, 51 (206): 291-326.

CARVALHO, F.J.C. (2000) "New competitive strategies of foreign banks in large emerging economies: the case of Brazil”, Banca Nazionale del Lavoro Quarterly Review, 53 (213): 135-170.

CARVALHO, F. C.R. HOFF and F.E.P. de SOUZA (2008) "Sistema financeiro e integração internacional: O caso do Brasil”, in Fanelli, J.M., Mercosur: integracion y profundizacion de los mercados financieros. Serie Red Mercosur no. 9. http://www.redmercosur.net/mercosur-integracion-y-profundizacion-de-los-mercados-financieros/publicacion/90/es/.

CARVALHO, F. G. B. da SILVEIRA and F.E.P. de SOUZA (2008) "Brazil”, in Fanelli, José M. (org.) Macroeconomic Volatility, Institutions and Financial Architectures: The Developing World Londres: Palgrave MacMillan.

CARVALHO, F. J. HERMANN, L.L. de PAULA, R. SOBREIRA, P. SARNO and F. FERRARI Filho (2009), Perspectivas da Indústria Financeira Brasileira e o Papel dos Bancos Públicos, Relatório do Subprojeto: Mercado de Títulos Brasileiro, projeto BNDES/IE-Unicamp/IE-UFRJ, unpublished.

CARVALHO, F. and F.E.P. de SOUZA (2009), Financial Regulation and Macroeconomic Stability in Brazil in the Aftermath of the Russian Crisis.. Documentos Técnicos ITF, 2009. http://www.ift. org.ar/documentos.asp.

CINTRA, M.A.M. and D. PRATES (2004), Os fluxos de capitais internacionais para o Brasil desde os anos 90. Available at: http://www.rls.org.br/publique/media/Controle_Cintra_Prates.pdf.

Committee on the Global Financial System - CGFS (1999) "A review of financial market events in Autumn 1998”, CGFS Publications number 12, http://www.bis.org/publ/cgfs12.htm, October.

CORDEN, W. Max (2002), Too Sensational: On the Choice of Exchange Rate Regimes. Cambridge (Mass) MIT Press.

FRANCO, G. and D.M. PINHO NETO (2004) “A desregulamentação da conta de capitalis: limitações macroeconômicas e regulatórias”. Available at: http://www.econ.puc-rio.br/gfranco.

GALA, P. (2009), “Propostas para a política cambial”. Valor Econômico, 10/6/2009.

IBGE/ANDIMA (1997), Sistema Financeiro. Uma Análise a partir das Contas Nacionais 1990-1995, Rio de Janeiro: Andima.

LOPES, F. (2003) "Notes on the Brazilian Crisis of 1997-99", The Brazilian Journal of Political Economy, vol. 23, no. 3 (91), pp. 35-62.

PASTORE, A.C. (2008), "Inflação: algumas lições da história”. Valor Econômico, 16/6/2008.

OSTRY, J., A. GHOSH, K. HABERMEIERS, M. CHAMON, M. QURESHI and D. REINHARDT (2010), "Capital inflows: The role of controls", IMF Staff Position Note, SPN/10/04.

SOUZA, F.E.P. (1999), “A política de câmbio do plano real (1994-1998): Especificidades da âncora brasileira". Revista de Economia Contemporânea, no. 5, pp. 37-56.

SOUZA, F.E.P. (1993), "O novo regime cambial brasileiro e suas consequências para a política econômica”. BNDES Discussion Papers, no. 18.

SOUZA, F.E.P. (2005), "Sem medo de flutuar? O regime cambial brasileiro pós 1988". Estudos Econômicos, São Paulo, V. 35 (3), pp. 519-545.

SOUZA, F.E.P. (2009) "Da reativação da economia ao crescimento de longo prazo: a questão da competitividade e do câmbio", Paper prepared for the Special Forum of the Instituto Nacional de Altos Estudos, Available at: http://www.forumnacional.org.br/sec.php?s=620\&i=pt\&cod=A0225. 